\title{
PENAMBAHAN KALSIUM KARBONAT PADAPEMBUATAN TEPUNG PUDING INSTAN BERBAHAN ALGINAT
}

\section{Addition of Calcium Carbonate on the Production of Instant Pudding Powder Containing Alginate}

\author{
Dina Fransiska ${ }^{*}$, Annisa Indah Permatasari², Sakinah Haryati ${ }^{2}$, Aris Munandar ${ }^{2}$, \\ Subaryono', Muhamad Darmawan', dan Wahyu Rahmad' \\ ${ }^{1}$ Balai Besar Penelitian dan Pengembangan Pengolahan Produk dan Bioteknologi Kelautan dan Perikanan, \\ JI. K.S. Tubun Petamburan VI, Jakarta Pusat, Indonesia \\ 2 Fakultas Pertanian, Universitas Sultan Ageng Tirtayasa, Indonesia \\ * Korespondensi Penulis: dinanomo@gmail.com
}

Diterima: 6 Februari 2014; Disetujui: 4 Juni 2014

\begin{abstract}
ABSTRAK
Penelitian mengenai penambahan kalsium karbonat pada pembuatan tepung puding instan berbahan alginat telah dilakukan. Tujuan penelitian ini adalah menentukan konsentrasi $\mathrm{CaCO}_{3}$ terbaik pada pembuatan tepung puding instan berbahan alginat yang diekstrak dari rumput laut coklat Sargassum filipendula dan menentukan karakteristik mutu tepung puding terbaik. Formulasi tepung puding terdiri atas alginat, guar gum, $\mathrm{CaCO}_{3}$, perisa strawberry, pewarna, gula jagung, dan susu skim serta bahan pembentuk gel yaitu Glucono- $\delta$-lactone. Pengujian produk puding instan dari alginat dilakukan terhadap sifat fisik yaitu kekuatan gel, elastisitas, sineresis dan uji organoleptik. Pada uji organoleptik, parameter yang dinilai meliputi tekstur, rasa, kenampakan, dan aroma. Formulasi produk tepung puding instan terbaik pada penelitian ini adalah tepung puding dengan penambahan $\mathrm{CaCO}_{3}$ konsentrasi $5 \%$ yang menghasilkan puding dengan kekuatan gel $168,84 \mathrm{~g} / \mathrm{cm}^{2}$, elastisitas $43,09 \mathrm{~mm}$, dan sineresis $3,38 \%$. Pada hasil uji organoleptik, puding instan terpilih mendapatkan nilai rata-rata uji rangking 45 (sangat suka), uji sensori kenampakan 3,00 (netral), aroma 4,33 (suka), rasa 3,27 (netral) dan tekstur 4,00 (suka). Mutu tepung puding instan terbaik memiliki kadar air 2,70 $\pm 0,13 \%$, kadar abu $14,96 \pm 3,57 \%$, kadar lemak $0,41 \pm 0,08 \%$, kadar protein $3,67 \%$, kadar karbohidrat by difference $78,26 \%$ dan $a_{w} 0,23 \pm 0,01$. Sedangkan pada analisis mikrobiologi tepung puding instan terbaik memiliki nilai rata-rata angka lempeng total $(\mathrm{ALT})<25 \times 10^{2} \mathrm{koloni} / \mathrm{g}$.
\end{abstract}

KATAKUNCl: puding instan, alginat, glucono-ס-lactone, kalsium karbonat

\section{ABSTRACT}

Research on addition of calcium carbonate on the production of instant pudding powder containing alginate has been done. The purpose of this study was to determine the best $\mathrm{CaCO}_{3}$ concentration in the production of instant pudding powder made from alginate extracted from brown seaweed Sargassum filipendula and to determine the characteristics of the best quality of pudding powder. Pudding powder formulation was comprising of alginate, guar gum, $\mathrm{CaCO}_{3}$, strawberry flavor, colouring, corn sugar, and skim milk as well as gel-forming material ie. Glucono$\delta$-lactone. Analysis of instant pudding alginate was performed on gel strength, elasticity, syneresis and organoleptic. In the organoleptic test, characteristics parameters being assessed were texture, flavor, appearance and aroma. The best instant pudding powder formula in this study is the pudding powder with the addition of $5 \% \mathrm{CaCO}_{3}$ having gel strength of $168.84 \mathrm{~g} / \mathrm{cm}^{2}$, elasticity of $43.09 \mathrm{~mm}$ and syneresis of $3.38 \%$. In the organoleptic test, the selected instant pudding had an average value rank test of 45 (really like), appearance of 3.00 (neutral), flavor of 4.33 (like), taste of 3.27 (neutral) and texture of 4.00 (like). Quality analysis showed that the best instant pudding powder had a moisture content of $2.70 \pm 0.13 \%$, ash content of $14.96 \pm 3.57 \%$, fat content of 0.41 $\pm 0.08 \%$, protein content of $3.67 \%$, carbohydrate by difference of $78.26 \%$ and $a_{w}$ of $0.23 \pm 0.01$. While the result of microbiological analysis showed that best instant pudding powder had an average value of total plate count $(A L T)<25 \times 102$ colonies $/ g$.

KEYWORDS: instan pudding, alginate, Glucono-ס-lactone, calsium carbonate 


\section{PENDAHULUAN}

Potensi sumber daya laut Indonesia sangat tinggi salah satunya dalam produksi rumput laut. Salah satu jenis potensi rumput laut yang dapat dimanfaatkan adalah rumput laut coklat. Selama ini, pemanfaatan rumput laut coklat masih sangat rendah khususnya Sargassum sp. yang potensinya berlimpah. Produksi rumput laut coklat di Indonesia sangat besar meskipun saat ini produksi riilnya baru sekitar 300 ton/tahun (Subaryono, 2011).

Rumput laut coklat diketahui memiliki kandungan hidrokoloid (alginat), protein, lemak, serat kasar, vitamin, dan zat antibakteri serta mineral (Yunizal, 2004). Selain itu, rumput laut coklat juga mengandung pigmen klorofil a dan c, beta karoten, violasantin dan fukosantin, pirenoid dan filakoid, cadangan makanan berupa laminaran serta dinding sel yang mengandung selulosa (Indriani \& Sumarsih, 1999). Rumput laut coklat penghasil alginat tertinggi berasal dari marga Sargassum. Alginat merupakan fikokoloid atau hidrokoloid yang diekstraksi dari rumput laut coklat yang disusun oleh dua unit monomerik yaitu $\alpha-D-$ mannuronic acid dan $\alpha$-L-guluronic acid (Anggadiredja et al., 2010). Menurut Siswati (2002), pemanfaatan alginat dalam bidang pangan sudah banyak digunakan seperti sebagai pengemulsi dan penstabil emulsi pada es krim, pensuspensi pada susu coklat, pembentuk bodi dan tekstur pada yoghurt, produk pangan restrukturisasi (daging dan buah) dan pembentukan gel pada jeli instan.

Puding merupakan salah satu jenis hidangan penutup yang banyak disukai karena rasanya yang manis dan teksturnya yang lembut. Pada umumnya puding dibuat dari tepung agar atau karaginan. Pada pembuatan puding berbahan dasar agar atau karaginan, harus melibatkan proses pemanasan pada pembuatan pudingnya karena kedua bahan tersebut tidak larut dalam air dingin. Pada dasarnya puding juga dapat dibuat dari fikokoloid lainnya seperti alginat. Kelebihan tepung puding berbahan dasar alginat dibandingkan dengan tepung puding berbahan dasar agar atau karaginan adalah kemampuannya membentuk gel tanpa perlu adanya pemanasan. Hal ini merupakan kelebihan dari tepung puding berbahan alginat, yang pada suhu ruang dapat membentuk gel dengan adanya ion kalsium atau kation logam polivalen lainnya yang ditambahkan (Winarno, 1996).

Alginat berpotensi digunakan sebagai bahan pembentuk gel puding, sebagai imobilisasi dan binder karena karakteristik gelnya yang kuat seperti agar dan karaginan dengan penambahan $\mathrm{CaCO}_{3}$ dan Glucono-ס-lactone (GDL) (Subaryono et al., 2010). Kalsium Karbonat $\left(\mathrm{CaCO}_{3}\right)$ digunakan sebagai agen pembentuk gel pada alginat. Pembentukan gel secara internal dilakukan untuk menghasilkan gel yang homogen dengan melepaskan ion kalsium dari senyawa atau kompleks dengan pengaturan kondisi di dalam sistem. Aktivasi dari ion pembentuk ikatan silang ini dilakukan dengan perubahan $\mathrm{pH}$ oleh penambahan asam organik atau lakton. Penurunan $\mathrm{pH}$ menyebabkan lepasnya ion $\mathrm{Ca}^{2+}$ dari $\mathrm{CaCO}_{3}$ atau senyawa kompleksnya dan akan bereaksi dengan alginat membentuk gel. Glucono- $\delta$-lactone (GDL) merupakan agen untuk penurunan $\mathrm{pH}$ secara perlahan sehingga alginat dapat membentuk gel yang sempurna. Berdasarkan hal tersebut maka dilakukan penelitian yang memanfaatkan alginat dalam pembuatan puding instan dengan penambahan $\mathrm{CaCO}_{3}$.

Tujuan penelitian ini adalah menentukan konsentrasi $\mathrm{CaCO}_{3}$ terbaik pada pembuatan tepung puding instan berbahan alginat yang diekstrak dari rumput laut coklat Sargassum filipendula dan menentukan karakteristik mutu tepung puding terbaik.

\section{BAHAN DAN METODE}

\section{Bahan}

Rumput laut coklat kering Sargassum filipendula yang digunakan pada penelitian ini berasal dari perairan Binuangeun, Banten. Bahan-bahan yang digunakan untuk ekstraksi alginat adalah $\mathrm{NaOCl}$, $\mathrm{Na}_{2} \mathrm{CO}_{3}, \mathrm{HCl}$, dan $\mathrm{NaOH}$. Sedangkan bahan untuk pembuatan puding adalah alginat, guar gum, $\mathrm{CaCO}_{3}$, perisa strawberry, pewarna, gula jagung, susu skim dan Glucono-ס-lactone.

\section{Metode}

\section{Penyiapan tepung natrium alginat}

Tepung natrium alginat diperoleh dari hasil ekstraksi dari rumput laut Sargassum filipendulla dengan menggunakan metode yang dikembangkan Murdinah et al. (2005).

\section{Formulasi tepung puding alginat}

Alginat hasil ekstraksi digunakan sebagai bahan dasar tepung puding instan. Formulasi menggunakan metode yang dikembangkan Peranginangin et al. (2010) dengan modifikasi (Tabel 1). Pembuatan puding instan dilakukan dengan melarutkan bahan-bahan pada Tabel 1 dalam $150 \mathrm{ml}$ air, setelah semua bahan larut kemudian ditambahkan Glucono- $\delta$-lactone $(6 \%)$, dan dibiarkan selama 2 menit hingga terbentuk gel (Gambar 1). 
Tabel 1. Formula bahan pembuatan puding instan

Table 1. Formula of instant pudding ingredients

\begin{tabular}{lrrrr}
\hline \multirow{2}{*}{ Bahan/Ingredients } & \multicolumn{4}{c}{ Komposisi/Composition (\%) } \\
\cline { 2 - 5 } & \multicolumn{1}{c}{ A } & \multicolumn{1}{c}{ B } & \multicolumn{1}{c}{ C } & \multicolumn{1}{c}{ D } \\
\hline Alginat/Alginate & 10 & 10 & 10 & 10 \\
Guar gum & 1 & 1 & 1 & 1 \\
CaCO $_{3}$ & 1 & 3 & 5 & 7 \\
Perisa/Essens & 0.54 & 0.54 & 0.54 & 0.54 \\
Pewarna/Colouring & 0.07 & 0.07 & 0.07 & 0.07 \\
Gula jagung/Corn sugar & 50 & 50 & 50 & 50 \\
Susu skim/Skim milk & 10 & 10 & 10 & 10 \\
\hline
\end{tabular}

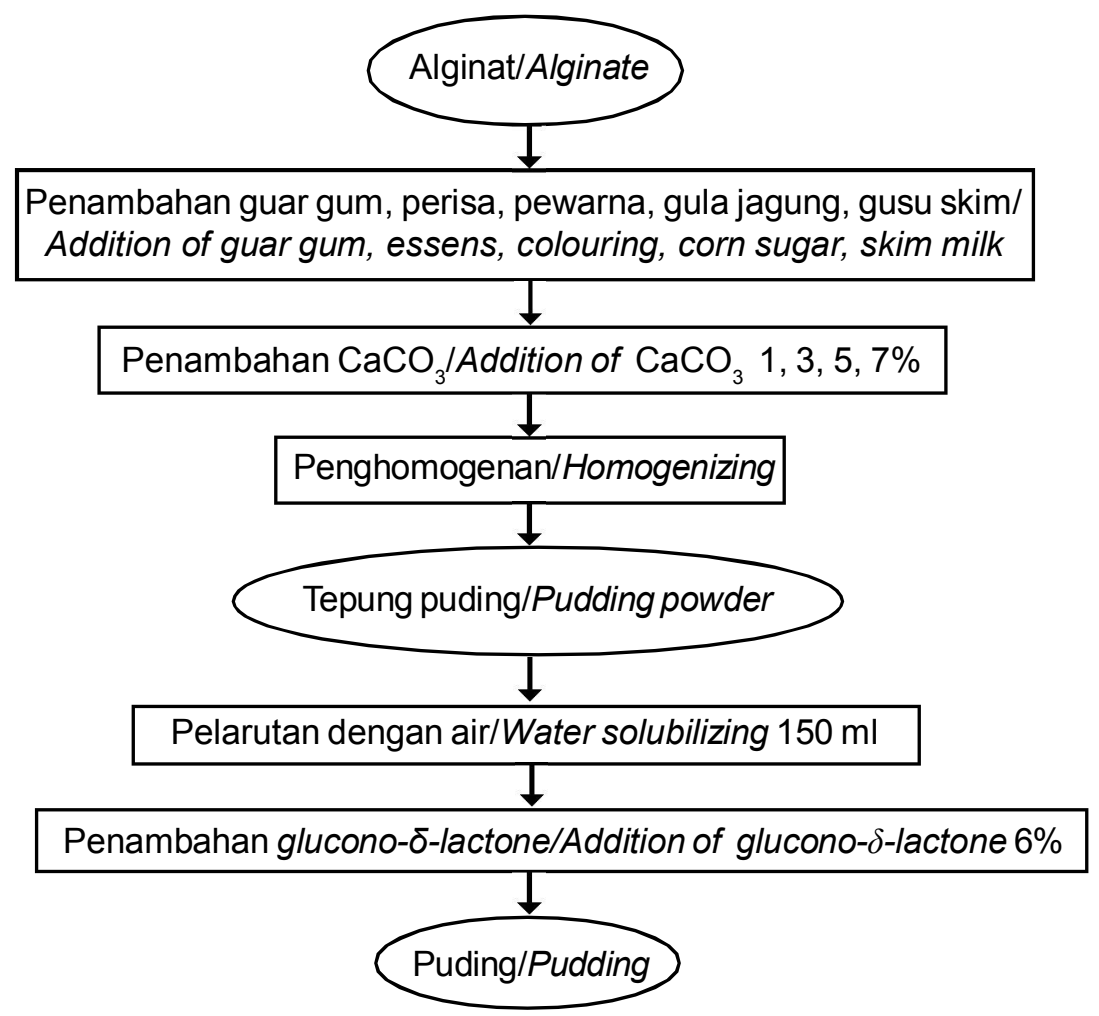

Gambar 1. Diagram alir proses pembuatan puding instan alginat.

Figure 1. Flow diagram of the process of instant pudding alginate production.

\section{Pengamatan}

Analisis mutu rumput laut coklat Sargassum filipendula meliputi kadar air (BSN, 2006a), kadar pengotor (impuritis) (Marine Colloids, 1977), dan Clean Anhydrous Weed/CAW (Marine Colloids, 1977) sedangkan mutu tepung natrium alginat hasil ekstraksi diamati terhadap kadar air dan kadar abu (BSN, 2006a), viskositas, rendemen (Marine Colloids, 1977), dan derajat putih (Food Chemical Codex, 1981).
Pengujian produk puding instan dari alginat Sargassum filipendula dilakukan terhadap analisis fisik yaitu kekuatan gel (Marrs \& Titoria, 2004), elastisitas, dan sineresis (Draget et al., 2001) dan uji organoleptik (BSN, 2011). Uji organoleptik dilakukan pada puding yang diolah dengan perbedaan konsentrasi $\mathrm{CaCO}_{3}$ yang meliputi uji hedonik dan uji rangking. Pada uji hedonik, karakteristik parameter yang dinilai oleh panelis semi terlatih meliputi tekstur, rasa, kenampakan, dan aroma dengan skala nilai 1 (sangat 
tidak suka) sampai 5 (sangat suka). Pada uji rangking, panelis mengurutkan sampel berdasarkan tingkat kesukaannya secara keseluruhan. Penilaian pada uji rangking menggunakan lima skala yaitu sangat suka, suka, biasa, tidak suka dan sangat tidak suka. Rangking 1 berarti sampel yang sangat disukai oleh panelis dan rangking 5 berarti sampel yang sangat tidak disukai oleh panelis.

Analisis kimia yang dilakukan pada tepung puding instan alginat terpilih terdiri atas kadar air dan kadar abu, kadar lemak, kadar protein (BSN, 2006a), kadar karbohidrat dan $a_{w}($ AOAC, 1994). Analisis mikrobiologi yang dilakukan pada produk puding instan terpilih dan produk komersil yaitu Angka Lempeng Total/ALT (BSN, 2006b).

Rancangan percobaan yang digunakan dalam penelitian ini adalah rancangan acak lengkap (RAL) dengan 4 perlakuan dan 3 kali ulangan. Data yang diperoleh dari hasil penelitian dianalisis dengan analisis ragam ANOVA, bila hasil analisis terdapat pengaruh nyata dilakukan uji lanjut Duncan. Analisis data untuk hasil pengujian organoleptik dilakukan dengan menggunakan uji statistik non parametrik yaitu Friedman Test dan Kruskal-Wallis.

\section{HASIL DAN PEMBAHASAN}

\section{Karakteristik Rumput Laut Coklat Sargassum filipendula}

Analisis rumput laut coklat kering dilakukan untuk mengetahui kondisi awal dari rumput laut yang akan diekstraksi. Hasil analisis rumput laut coklat kering ditampilkan pada Tabel 2.

Berdasarkan Tabel 2 dapat dilihat bahwa nilai kadar air lebih tinggi dari standar yang telah ditetapkan oleh SNI (BSN, 2009) yaitu maksimal $35 \%$. Tingginya nilai kadar air diduga karena pada proses pengeringan rumput laut tidak kering secara merata karena dikeringkan di bawah sinar matahari. Hak dan Tazwir (2004): Winarno (2008) menyatakan bahwa perbedaan nilai kadar air ini dapat disebabkan oleh perbedaan waktu dan proses pengeringan yang dilakukan. Pada penelitian ini penjemuran rumput laut coklat Sargassum filipendula dilakukan selama 2 hari di bawah sinar matahari.

Kadar pengotor dan CAW masih memenuhi SNI (BSN, 2009) yaitu maksimal 5\%. Nilai kadar pengotor yang rendah dikarenakan oleh proses sortasi rumput laut yang dilakukan dengan benar. Darmawan et al. (2013) menyatakan bahwa peningkatan metode budidaya, waktu panen, dan penanganan pada rumput laut yang baik dapat meningkatkan kualitas rumput laut yang dihasilkan. Clean Anhydrous Weed memberikan informasi mengenai kemurnian rumput laut, yaitu kebersihan rumput laut dari kotoran, pasir, batu karang dan campuran rumput laut lain (Subaryono \& Murdinah 2011).

\section{Karakteristik Natrium Alginat}

Karakteristik mutu natrium alginat dari rumput laut coklat Sargassum filipendula ditampilkan pada Tabel 3.

Hasil analisis kadar air, kadar abu, viskositas, dan rendemen natrium alginat hasil ekstraksi pada penelitian ini telah memenuhi standar yang ditetapkan oleh FCC (1981). Air yang terkandung dalam bahan dapat mempengaruhi tekstur, daya simpan, cita rasa dan penampakannya. Kadar abu menunjukkan kandungan mineral dalam suatu produk. Menurut Winarno (1996) kandungan abu pada produk menunjukkan kemurnian produk yang dipengaruhi oleh kandungan mineral bahan baku. Alga coklat temasuk bahan yang mengandung mineral cukup tinggi seperti $\mathrm{Na}, \mathrm{Ca}, \mathrm{K}, \mathrm{Cl}, \mathrm{Mg}, \mathrm{Fe}$, dan S.

Derajat putih merupakan parameter yang digunakan untuk menentukan tingkat warna putih dari suatu produk. Nilai derajat putih ini lebih tinggi dibandingkan nilai derajat putih $\mathrm{Na}$ alginat hasil penelitian Yunizal (2004). Tingginya nilai derajat putih pada natrium alginat akan berpengaruh terhadap warna tepung puding yang dihasilkan, puding lebih cerah dan tidak kusam.

Tabel 2. Karakteristik rumput laut coklat Sargassum filipendulla

Table 2. Characteristics of brown seaweed Sargassum filipendulla

\begin{tabular}{lcc}
\hline \multicolumn{1}{c}{ Parameter/Parameters } & Nilai/Value (\%) & BSN (2009) \\
\hline Kadar Air/Moisture content (\%) & $36.67 \pm 0.18$ & Maksimal/Max 35 \\
Kadar Pengotor/Impuritis (\%) & $3.58 \pm 0.31$ & Maksimal/Max 5 \\
Clean Anhydrous Weed (CAW) & $52.13 \pm 4.48$ & Minimal/Min 30 \\
\hline
\end{tabular}


Tabel 3. Rendemen dan mutu fisiko kimia natrium alginat

Table 3. The yield and physicochemical of sodium alginate

\begin{tabular}{lccc}
\hline \multicolumn{1}{c}{ Parameter/Parameters } & $\begin{array}{c}\text { Na Alginat Hasil Penelitian/ } \\
\text { Sodium Alginate in This Study }\end{array}$ & $\begin{array}{c}\text { Na Alginat } \\
\text { (Subaryono, 2010) }\end{array}$ & FCC (1981) \\
\hline Kadar Air/Moisture content (\%) & $14.66 \pm 0.10$ & $13.46 \pm 0.31$ & maks. 15,00 \\
Kadar Abu/Ash content (\%) & $24.35 \pm 1.06$ & $20.77 \pm 0.02$ & $18.00-27.00$ \\
Derajat Putih/Whiteness & $53.98 \pm 2.45$ & $52.80^{*}$ & - \\
Viskositas/Viscosity (cPs) & 39.17 & $108 \pm 4$ & 27.00 \\
Rendemen/Yield (\%) & $18.94 \pm 0.85$ & $33.93 \pm 1.33 \%$ & 18.00 \\
\hline
\end{tabular}

Sumber/Source: * Yunizal (2004)

Viskositas merupakan parameter mutu untuk menentukan penilaian natrium alginat. Ramsden (2004) menyatakan bahwa umumnya viskositas alginat meningkat dengan meningkatnya konsentrasi, umur rumput laut, keberadaan ion kalsium dalam sistem dan meningkatnya proporsi asam guluronat dibandingkan mannuronat. Subaryono (2009) menambahkan bahwa viskositas alginat dipengaruhi oleh perbedaan jenis rumput laut coklat serta umur rumput laut yang digunakan sehingga menghasilkan panjang polimer serta urutan unit monomer (guluronat dan mannuronat) alginat yang berbeda. Rumput laut Sargassum filipendula yang digunakan oleh Subaryono \& Peranginangin (2010) memiliki panjang thallus $32,48 \pm 8,41 \mathrm{~cm}$ sehingga viskositas dan rendemen yang dihasilkan lebih tinggi. Sedangkan pada penelitian ini rumput laut coklat Sargassum filipendulla dipanen dengan panjang thallus yang lebih pendek yaitu 20-25 cm. Ketidakseragaman pengambilan bahan baku dapat terjadi karena rumput laut Sargassum filipendula tumbuh secara alami bukan hasil budidaya, sehingga penentuan umur panen menjadi sangat sulit. Selain itu, perbedaan nilai viskositas ini juga dapat terjadi karena perbedaan metode pengukuran. Subaryono dan Peranginangin (2010) melakukan pengukuran viskositas dengan Rapid Visco Analyzer (RVA) sedangkan pada penelitian ini menggunakan metode JECFA (2007).

Nilai rendemen yang besar pada alginat yang dihasilkan selain ditentukan oleh metode ekstraksi juga sangat ditentukan oleh jenis rumput laut, umur dan panjang thallus, bagian tanaman, dan kondisi lingkungan di mana rumput laut tersebut tumbuh (Soegiarto et al., 1978). Rendemen yang dihasilkan dari ekstraksi natrium alginat pada penelitian telah memenuhi standar FCC namun lebih rendah dibandingkan rendemen natrium alginat hasil penelitian Subaryono \& Peranginangin (2010), hal ini dikarenakan karakteristik rumput laut yang digunakan sebagai bahan baku memiliki panjang thallus yang berbeda. Sesuai dengan pernyataan Ramsden (2004) dan Jothisaraswathi et al. (2006), bahwa umumnya rendemen alginat meningkat dengan meningkatnya konsentrasi, umur rumput laut, meningkatnya keberadaan ion kalsium dalam sistem dan meningkatnya proporsi asam guluronat dibandingkan asam manuronat. Perbedaan nilai rendemen ini kemungkinan dapat terjadi karena perbedaan metode. Pada penelitian ini proses penyaringan menggunakan hydraulic press untuk menghilangkan kandungan selulosa sedangkan pada penelitian Subaryono \& Peranginangin (2010) ekstraksi menggunakan vibrator screen, sehingga selulosa tidak tersaring dan menyebabkan alginat masih terdapat kandungan selulosa yang meningkatkan rendemen alginat yang dihasilkan. Adanya kandungan selulosa membuat larutan alginat akan mengendap, tidak larut sempurna dan larutan menjadi keruh.

\section{Analisis Fisik Produk Puding Instan Alginat}

Analisis fisik produk puding instan alginat pada penelitian ini meliputi karakteristik tekstur (kekuatan gel dan elastisitas) dan sineresis.

\section{Kekuatan gel}

Kekuatan gel merupakan salah satu karakteristik mutu puding instan yang sangat penting. Salah satu sifat alginat adalah dapat membentuk gel yang uniform (seragam) yang hanya dimungkinkan bila larutan tersebut diaduk dengan baik sebelum pembuatan gel dicampur dengan beberapa asam (Winarno, 1996). Sifat alginat sebagai pembentuk gel dapat digunakan untuk pembuatan puding instan, pastry fillings, dan dessert gel (Renn, 1986). Nilai kekuatan gel puding instan alginat ditampilkan pada Gambar 2. 


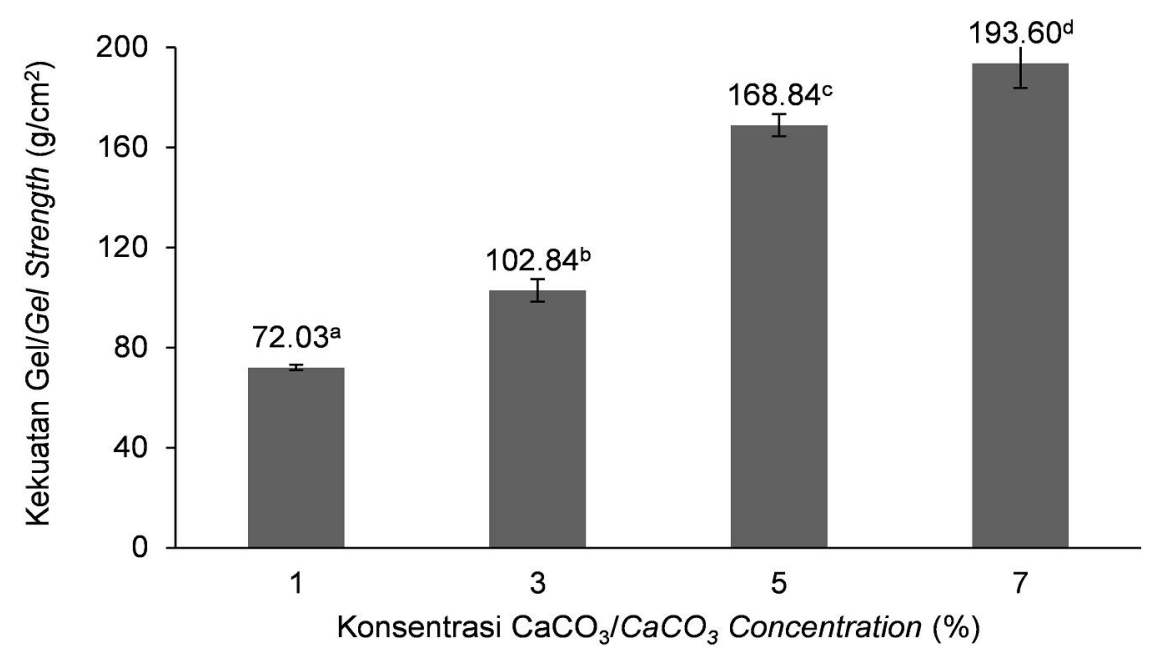

Keterangan/Note: Huruf superscript yang berbeda menunjukkan perbedaan nyata $(p<0,05) /$ Different superscript letters indicate significant differences $(p<0.05)$.

Gambar 2. Kekuatan gel puding instan alginat dengan konsentrasi $\mathrm{CaCO}_{3}$ yang berbeda.

Figure 2. The gel strength of alginate instant pudding of different $\mathrm{CaCO}_{3}$ concentration.

Hasil analisis menunjukkan bahwa terdapat perbedaan yang nyata terhadap kekuatan gel puding instan alginat dengan besarnya konsentrasi $\mathrm{CaCO}_{3}$. Uji lanjut yang dilakukan menunjukkan bahwa terdapat pengaruh yang berbeda dari perlakuan konsentrasi $\mathrm{CaCO}_{3}$ yang ditambahkan. Hasil penelitian menunjukkan nilai kekuatan gel puding instan alginat berkisar antara 72,03 sampai $193,60 \mathrm{~g} / \mathrm{cm}^{2}$. Nilai terendah kekuatan gel puding instan terdapat pada penambahan konsentrasi $\mathrm{CaCO}_{3} 1 \%$ dan nilai tertinggi terdapat pada penambahan konsentrasi $\mathrm{CaCO}_{3} 7 \%$.

Subaryono (2009) menyatakan bahwa dengan meningkatnya konsentrasi $\mathrm{CaCO}_{3}$ maka ion $\mathrm{Ca}^{2+}$ yang dilepaskan ke dalam sistem semakin banyak sehingga ikatan silang yang bisa terbentuk antar molekul alginat semakin banyak. Semakin banyak ikatan silang yang terbentuk maka gel yang dihasilkan akan semakin kuat. Sebaliknya pada konsentrasi $\mathrm{CaCO}_{3}$ rendah, homogenitas gel yang dihasilkan rendah maka dispersi $\mathrm{CaCO}_{3}$ dalam larutan kurang baik dan cepat mengendap. Bagian permukaan gel merupakan bagian yang paling kekurangan ion $\mathrm{Ca}^{2+}$ untuk pembentukan gel sehingga menghasilkan kekuatan gel yang rendah (Subaryono et al., 2010)

Pada penelitian ini pembentukan gel pada produk puding instan alginat dilakukan secara internal agar pelepasan ion $\mathrm{Ca}^{2+}$ dari $\mathrm{CaCO}_{3}$ berjalan dengan lambat sehingga akan menghasilkan gel yang kuat. Draget (2000) menyatakan bahwa pembentukan gel alginat secara internal dapat mengurangi ukuran partikel karbonat sehingga dapat meningkatkan permukaan larutan untuk masuknya asam dan mengurangi waktu transisi. Hasil gel yang terbentuk secara internal mendekati hasil gel yang terbentuk secara cepat.

\section{Elastisitas}

Sifat elastisitas sangat diperlukan pada pembuatan puding. Pengukuran elastisitas dilakukan dengan mengamati jarak yang diperlukan probe sampai titik puncak kekuatan gel oleh pengaruh tekanan dari probe yang diberikan. Produk yang semakin elastis akan membuat jarak probe yang dibutuhkan dalam menekan sampel sampai titik pecahnya semakin jauh (Subaryono, 2009). Nilai elastisitas puding instan alginat ditampilkan pada Gambar 3.

Hasil penelitian menunjukkan nilai elastisitas produk puding instan alginat antara 13,30-49,17 mm. Penambahan konsentrasi $\mathrm{CaCO}_{3} 1 \%$ menghasilkan elastisitas yang paling rendah dibandingkan penambahan konsentrasi $\mathrm{CaCO}_{3}$ lainnya, hal ini dikarenakan ion $\mathrm{Ca}^{2+}$ pada penambahan $\mathrm{CaCO}_{3} 1 \%$ belum cukup untuk membentuk gel.

Nilai elastisitas pada puding instan akan semakin tinggi dengan semakin tingginya konsentrasi $\mathrm{CaCO}_{3}$ yang ditambahkan, hal ini dikarenakan ketersediaan sumber ion $\mathrm{Ca}^{2+}$ dalam puding tinggi sehingga menghasilkan gel yang baik dan berpengaruh terhadap peningkatan elastisitas gel. Lesmana et al. (2008) menyatakan bahwa semakin banyak $\mathrm{CaCO}_{3}$ yang ditambahkan maka pembentukan jembatan kalsium akan semakin banyak sehingga berpengaruh terhadap daya tarik yang dibutuhkan untuk memutus matriks gel yang terbentuk. 


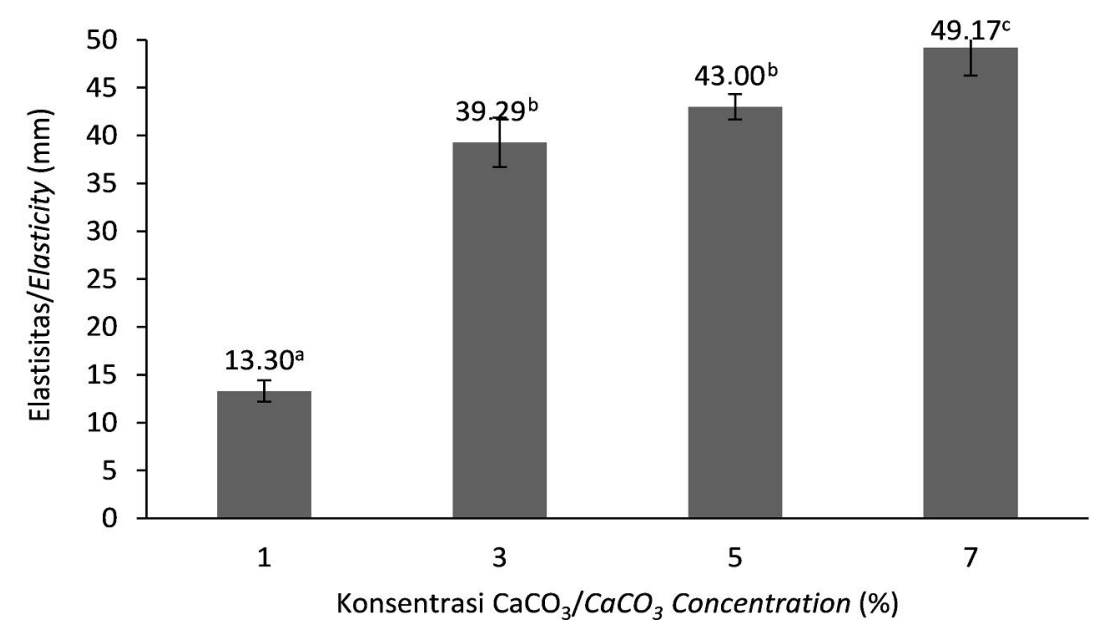

Keterangan/Note: Huruf superscript yang berbeda menunjukkan perbedaan nyata $(p<0,05) /$ Different superscript letters indicate significant differences $(p<0.05)$.

Gambar 3. Nilai elastisitas puding instan alginat dengan konsentrasi $\mathrm{CaCO}_{3}$ yang berbeda.

Picture 3. Elasticity of alginate instant pudding of different $\mathrm{CaCO}_{3}$ concentrations.

Penambahan konsentrasi $\mathrm{CaCO}_{3} 3 \%$ tidak berbeda nyata dengan penambahan konsentrasi $\mathrm{CaCO}_{3} 5 \%$, namun berbeda nyata dengan penambahan konsentrasi $\mathrm{CaCO}_{3} 7 \%$. Subaryono (2009) menyatakan bahwa peningkatan konsentrasi $\mathrm{CaCO}_{3}$ akan meningkatkan kekuatan gel alginat dan berpengaruh terhadap peningkatan elastisitasnya. Draget (2000) menyatakan bahwa meningkatnya ketersediaan ion $\mathrm{Ca}^{2+}$ pada alginat akan meningkatkan nilai elastisitas karena pertukaran ion yang terjadi semakin banyak dan sebaliknya menurunnya ketersediaan ion $\mathrm{Ca}^{2+}$ akan menurunkan nilai elastisitas karena pertukaran ion yang terjadi sedikit.

\section{Sineresis}

Sineresis merupakan peristiwa keluarnya air dalam gel. Menurut Draget et al. (2001), sineresis adalah karakteristik yang dapat terlihat pada proses terjadinya

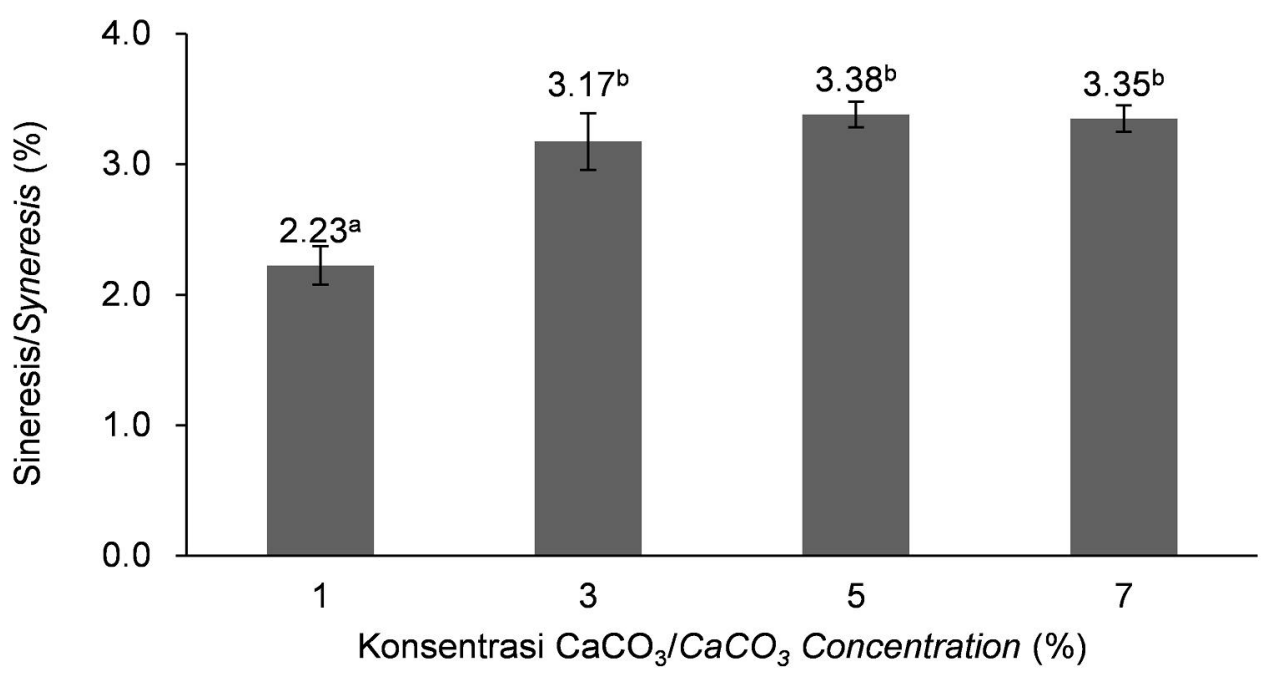

Keterangan/Note: Huruf superscript yang berbeda menunjukkan perbedaan nyata $(p<0,05) /$ Different superscript letters indicate significant differences $(p<0.05)$.

Gambar 4. Nilai sineresis puding instan alginat dengan konsentrasi $\mathrm{CaCO}_{3}$ yang berbeda.

Figure 4. Syneresis value of alginate instant pudding of different $\mathrm{CaCO}_{3}$ concentrations. 
pengkerutan gel yang bersifat lambat yang dipengaruhi oleh waktu dan mengakibatkan terlepasnya cairan dari gel. Sineresis dalam suatu gel terlihat dari banyaknya air yang dilepaskan gel oleh pengaruh penyimpanan. Nilai sineresis puding instan alginat ditampilkan pada Gambar 4.

Hasil penelitian menunjukkan nilai sineresis puding antara 2,23\%-3,38\%. Semakin tinggi penambahan $\mathrm{CaCO}_{3}$ semakin tinggi nilai sineresisnya. Penambahan konsentrasi $\mathrm{CaCO}_{3} 3 \%$ meningkatkan nilai sineresis dibandingkan dengan penambahan konsentrasi $\mathrm{CaCO}_{3} 1 \%$. Subaryono et al. (2010) menyatakan bahwa semakin tinggi ikatan yang terjadi maka daya tarik antar molekul alginat semakin kuat, pengerutan gel yang mungkin terjadi semakin tinggi, dan air yang dilepaskan dari gel semakin tinggi. Draget et al. (2001) menyatakan bahwa sineresis pada gel alginat dipengaruhi konsentrasi ion $\mathrm{Ca}^{2+}$ yang digunakan untuk pembentukan gel. Jika ketersediaan ion $\mathrm{Ca}^{2+}$ ke dalam sistem kecil maka ikatan silang yang dapat terbentuk antar molekul sedikit dan menyebabkan nilai sineresis semakin kecil.

Dari Gambar 4 terlihat bahwa penambahan $\mathrm{CaCO}_{3}$ pada konsentrasi $3 \%$ sudah menyediakan ion $\mathrm{Ca}^{2+}$ yang berlebih sehingga peningkatan konsentrasi selanjutnya ( $5 \%$ dan $7 \%$ ) tidak memberikan efek yang nyata lagi terhadap nilai sineresis.

\section{Karakteristik Sensori Puding Instan}

Analisis sensori puding instan alginat yang dilakukan pada penelitian ini meliputi uji pembedaan atribut dan uji rangking.

\section{Uji pembedaan atribut}

Uji pembedaan atribut menggambarkan karakteristik dari puding instan yang dinilai oleh panelis melalui parameter-parameter yang ada pada puding instan tersebut. Karakteristik parameter yang dinilai oleh panelis meliputi tekstur, rasa, kenampakan, dan aroma dengan skala nilai 1 (sangat tidak suka) sampai 5 (sangat suka).

\section{Tekstur}

Salah satu faktor yang menentukan penerimaan konsumen terhadap puding instan adalah tekstur. Winarno (2008) meyatakan bahwa tekstur merupakan ciri khas dari suatu produk dan kriteria utama dalam menduga kualitas makanan. Hasil pengujian sensori parameter tekstur puding instan alginat menunjukkan nilai antara 3,67 sampai 4,93 (suka sampai sangat suka). Nilai tekstur pada puding instan alginat ditampilkan pada Gambar 5.

Hasil analisis Kruskal-Wallis menunjukkan bahwa penambahan $\mathrm{CaCO}_{3}$ tidak memberikan pengaruh yang berbeda nyata terhadap nilai parameter tekstur puding instan dari alginat. Hal ini diduga karena panelis tidak dapat mendeteksi adanya perbedaan tekstur antar perlakuan walaupun secara uji kekuatan gel terlihat berbeda nyata.

\section{Rasa}

Rasa merupakan komponen utama dalam menentukan tingkat penerimaan suatu produk, karena rasa dapat membuat produk menjadi lebih bernilai dan disukai oleh konsumen (Effendi, 2009). Hasil pengujian

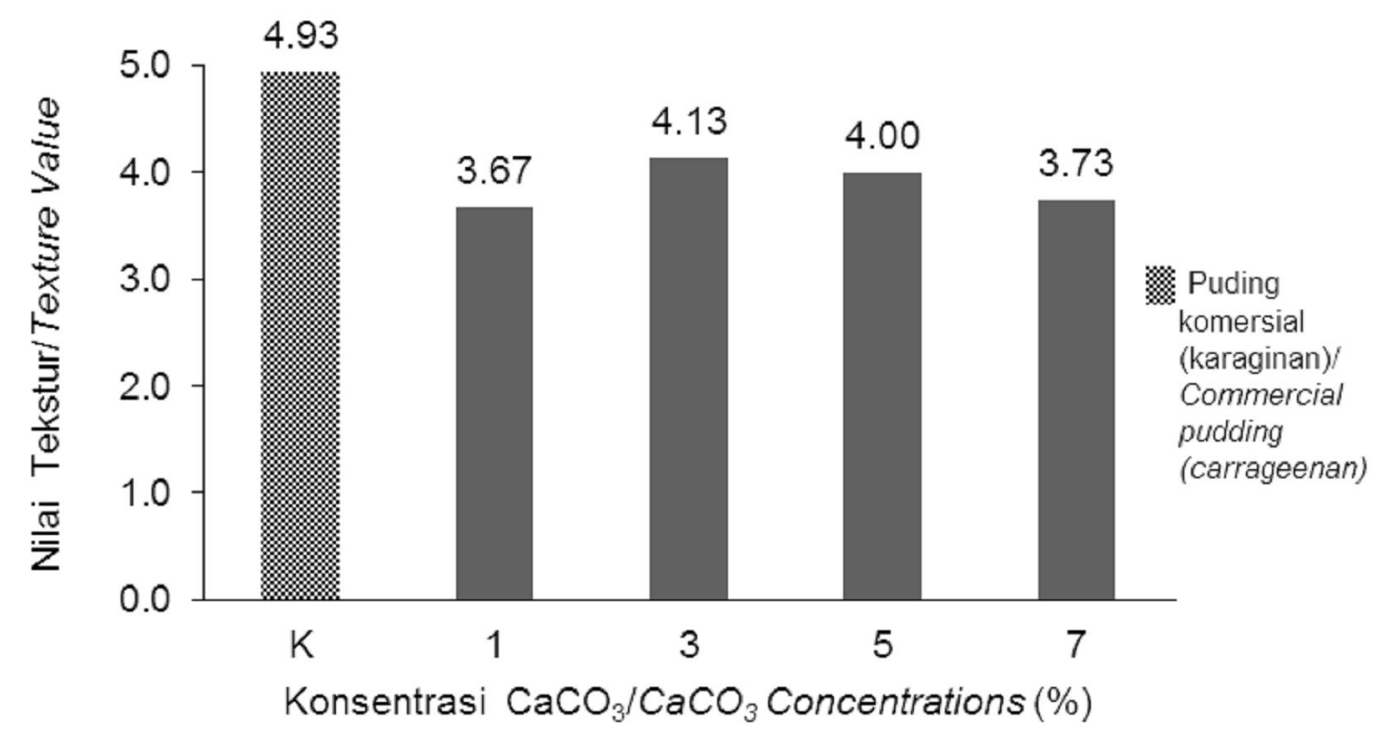

Gambar 5. Nilai tekstur pada puding instan alginat pada konsentrasi $\mathrm{CaCO}_{3}$ berbeda. Figure 5. Texture values of alginate instant pudding of different $\mathrm{CaCO}_{3}$ concentrations. 


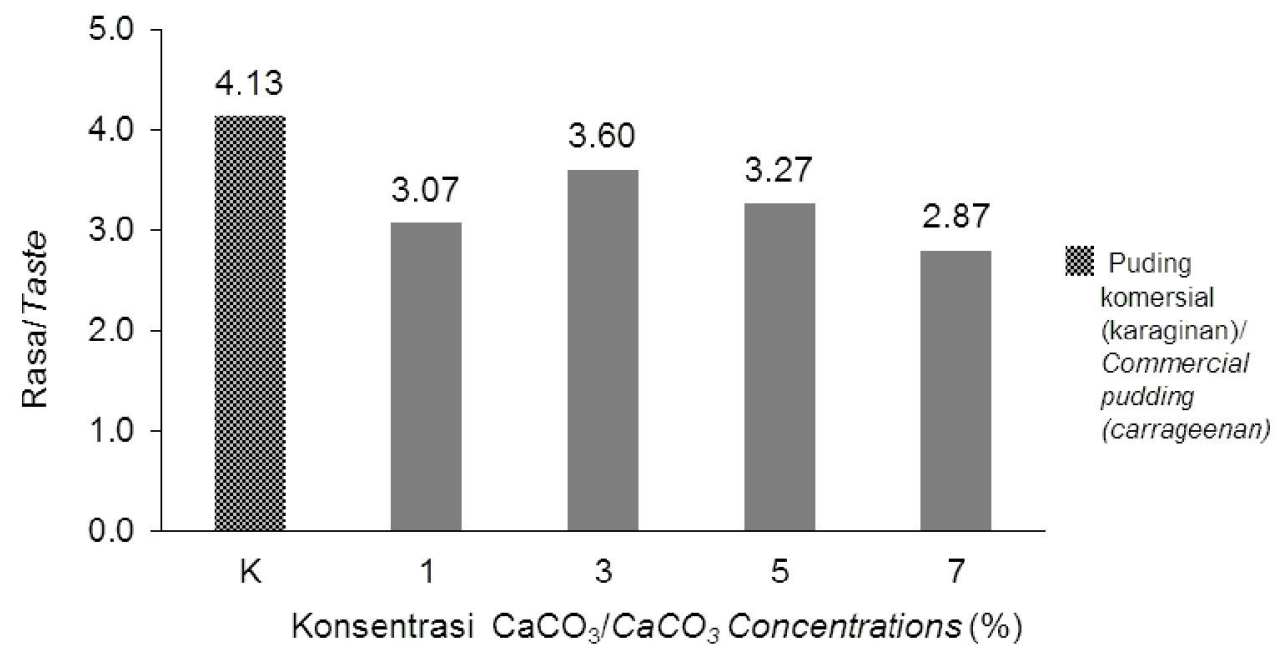

Gambar 6. Nilai rasa pada puding instan alginat pada konsentrasi $\mathrm{CaCO}_{3}$ yang berbeda.

Figure 6. Taste values of alginate instant pudding of different $\mathrm{CaCO}_{3}$ concentrations.

sensori parameter rasa puding instan alginat menunjukkan nilai antara 2,87 sampai 4,13 (biasa sampai suka). Nilai rasa pada puding instan alginat ditampilkan pada Gambar 6.

Hasil analisis Kruskal-Wallis menunjukkan bahwa penambahan konsentrasi $\mathrm{CaCO}_{3}$ tidak memberikan pengaruh yang berbeda nyata terhadap nilai rasa puding instan alginat, karena $\mathrm{CaCO}_{3}$ tidak memiliki rasa yang cukup kuat (rasa seperti kapur). Gambar 6 menunjukkan bahwa rasa pada puding pembanding komersial lebih disukai dibandingkan puding instan alginat, karena puding instan alginat menggunakan gula jagung yang kemanisannya lebih rendah dibandingkan gula tebu, sehingga panelis lebih menyukai puding pembanding komersil yang rasanya lebih manis.

\section{Kenampakan}

Kenampakan merupakan salah satu faktor yang mempengaruhi pilihan konsumen terhadap suatu produk. Kenampakan merupakan sifat sensori yang memberikan kesan pertama pada konsumen untuk melihat produk tersebut baik atau disukai, sebelum melihat sifat sensori lainnya seperti aroma, tekstur, dan rasa. Hasil pengujian sensori parameter kenampakan puding instan alginat menunjukkan nilai antara 3,07 sampai 4,33 (biasa sampai suka). Nilai parameter kenampakan pada puding instan alginat ditampilkan pada Gambar 7.

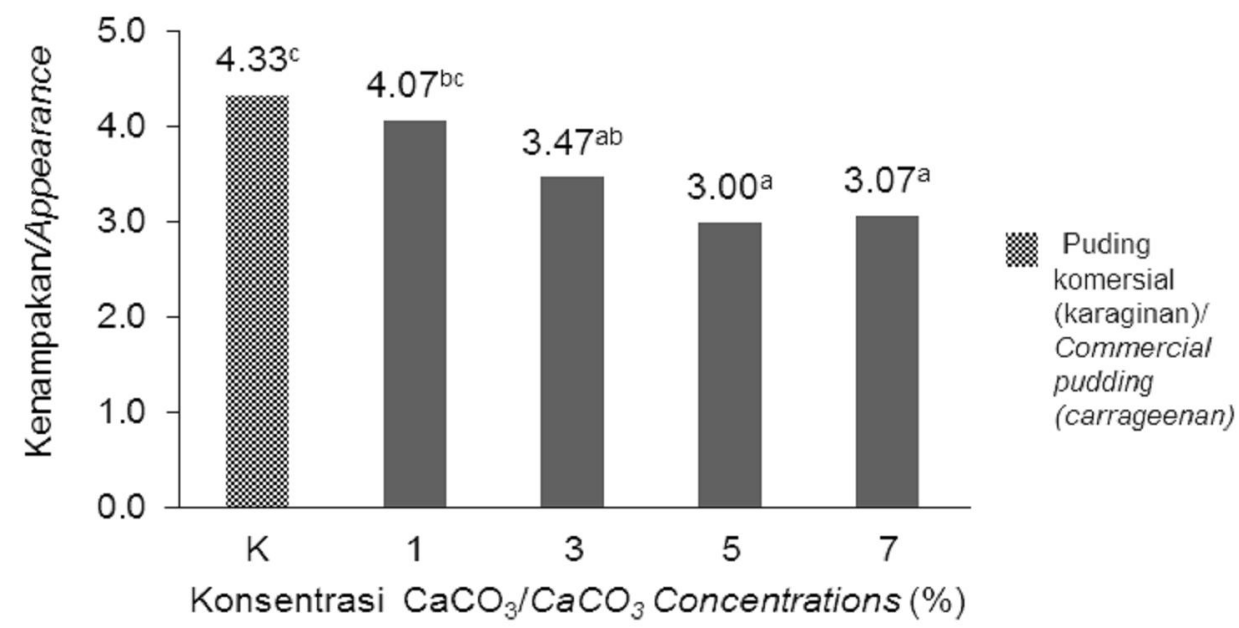

Keterangan/Note: Huruf superscript yang berbeda menunjukkan perbedaan nyata $(p<0,05) /$ Different superscript letters indicate significant differences $(p<0.05)$

Gambar 7. Nilai kenampakan puding instan alginat pada konsentrasi $\mathrm{CaCO}_{3}$ yang berbeda. Picture 7. Apperance values of alginate instant pudding of different $\mathrm{CaCO}_{3}$ concentrations. 
Gambar 7 menunjukkan bahwa semakin tinggi konsentrasi $\mathrm{CaCO}_{3}$ maka akan mempengaruhi kenampakan puding instan alginat yang menyebabkan menurunnya penerimaan panelis terhadap kenampakan puding. Nilai kenampakan puding yang memiliki tingkat kesukaan tertinggi yaitu puding instan pembanding komersial (suka), sebaliknya puding instan yang memiliki tingkat kesukaan terendah yaitu pada puding instan dengan penambahan konsentrasi $\mathrm{CaCO}_{3} 5 \%$ dan $7 \%$ (biasa).

Uji lanjut yang dilakukan menunjukkan bahwa puding dengan penambahan konsentrasi $\mathrm{CaCO}_{3} 1 \%$ tidak memberikan pengaruh yang berbeda nyata terhadap puding pembanding komersial. Namun puding dengan penambahan konsentrasi $\mathrm{CaCO}_{3} 3 \%$, $5 \%$ dan $7 \%$ berbeda nyata dengan puding pembanding komersial. Penambahan konsentrasi $\mathrm{CaCO}_{3}$ yang semakin tinggi akan mempengaruhi penampakan pada puding instan dari alginat sehingga membuat warna merah pada puding menjadi lebih muda. Sedangkan pada penambahan konsentrasi $\mathrm{CaCO}_{3}$ yang lebih rendah memberikan warna merah yang lebih kuat, sehingga memberikan penampakan yang lebih menarik pada puding instan dan menyamai warna puding pembanding komersial. Lesmana et al. (2008) menyatakan bahwa semakin tinggi $\mathrm{CaCO}_{3}$ yang ditambahkan maka warna putih pada produk semakin terang atau nampak jelas sehingga memberikan efek whitening pada produk yang ditambahkan $\mathrm{CaCO}_{3}$.

\section{Aroma}

Aroma lebih banyak berhubungan dengan panca indra pembau. Aroma dalam banyak hal menentukan enak atau tidaknya makanan. Pada umumnya bau yang diterima oleh hidung dan otak lebih banyak merupakan berbagai ramuan atau campuran empat bau utama yaitu harum, asam, tengik dan hangus (Winarno, 1996). Hasil pengujian sensori parameter aroma puding instan alginat menunjukkan nilai antara 4,27 sampai 4,60 (suka sampai sangat suka). Nilai pada parameter aroma puding instan alginat ditampilkan pada Gambar 8.

Gambar 8 menunjukkan bahwa penambahan konsentrasi $\mathrm{CaCO}_{3}$ yang berbeda tidak memberikan pengaruh aroma puding instan alginat terhadap tingkat kesukaan panelis. Nilai aroma yang memiliki tingkat kesukaan tertinggi yaitu pada puding instan pembanding komersial sebesar 4,60 (sangat suka) sedangkan puding instan dengan nilai terendah terdapat pada puding instan dengan penambahan $\mathrm{CaCO}_{3} 7 \%$ (suka) yang artinya aroma pada produk normal.

Aroma yang tercium pada puding instan dengan penambahan konsentrasi $\mathrm{CaCO}_{3}$ tidak memberikan aroma yang spesifik, dikarenakan terdapat aroma lain yang terbentuk dari susu skim, gula jagung, dan strawberry bubuk yang digunakan, yang menyebabkan aroma yang keluar normal serta kemungkinan terjadinya off flavour sangat lemah sehingga disukai oleh panelis.

\section{Uji ranking}

Uji ranking yang dilakukan terhadap puding instan pada masing-masing perlakuan berturut-turut dari ranking $1-5$ adalah pembanding komersial, $\mathrm{CaCO}_{3} 5 \%$, $\mathrm{CaCO}_{3} 3 \%, \mathrm{CaCO}_{3} 7 \%$, dan $\mathrm{CaCO}_{3} 1 \%$. Nilai terendah (sangat suka) terdapat pada puding instan pembanding komersial, sedangkan nilai rangking tertinggi (sangat tidak suka) terdapat pada puding

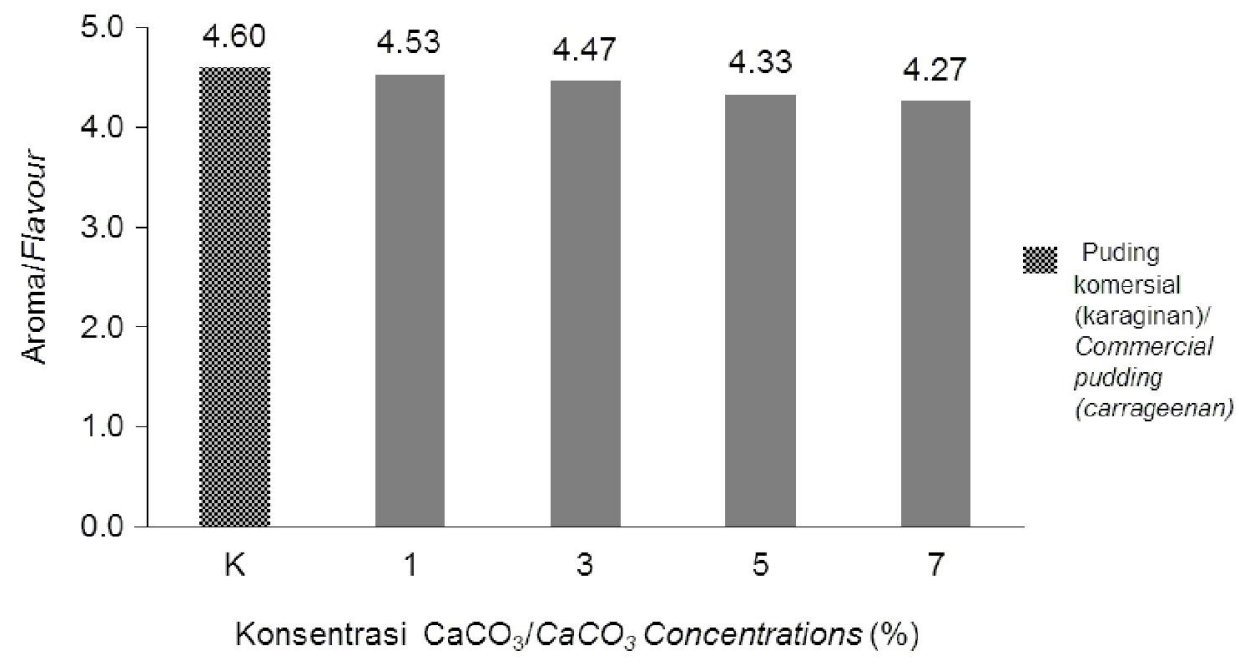

Gambar 8. Nilai aroma puding instan alginat pada konsentrasi $\mathrm{CaCO}_{3}$ yang berbeda. Figure 8. Flavor values of alginate instant pudding of different $\mathrm{CaCO}_{3}$ concentrations. 
instan dengan penambahan $\mathrm{CaCO}_{3} 1 \%$. Hal ini menunjukkan kecenderungan panelis menyukai puding instan pembanding komersial.

Hasil analisis menunjukkan bahwa penambahan $\mathrm{CaCO}_{3}$ memberikan pengaruh yang nyata terhadap tingkat kesukaan puding instan oleh panelis. Penambahan konsentrasi $\mathrm{CaCO}_{3} 1 \%$ pada puding instan alginat menghasilkan gel yang lemah, pembentukan gel pada puding belum sempurna sehingga tekstur gel yang dihasilkan lembek. Pada penambahan konsentrasi $\mathrm{CaCO}_{3} 3 \%$ gel yang dihasilkan puding mulai terbentuk sempurna walaupun masih terdapat bagian puding yang lembek. Gel pada puding instan alginat mulai terbentuk sempurna pada penambahan konsentrasi $\mathrm{CaCO}_{3} 5 \%$, semakin tinggi konsentrasi $\mathrm{CaCO}_{3}$ yang ditambahkan maka gel yang dihasilkan akan semakin kuat. Pada penambahan konsentrasi $\mathrm{CaCO}_{3} 7 \%$ gel yang terbentuk sangat sempurna namun gel yang dihasilkan menjadi lebih kaku, sehingga mempengaruhi penerimaan puding instan alginat oleh panelis. Draget (2000) menyatakan bahwa kandungan poliguluronat yang semakin tinggi didalam alginat maka akan menghasilkan gel yang lebih kuat dan tekstur yang dihasilkan lebih kaku.

\section{Kriteria Puding Instan Terbaik dan Karakteristiknya}

Penentuan perlakuan terbaik dari puding instan alginat dengan penambahan konsentrasi $\mathrm{CaCO}_{3} 1 \%$, 3,5 , dan $7 \%$ didasarkan pada nilai penerimaan panelis secara sensori yang ditentukan berdasarkan uji Ranking. Berdasarkan Gambar 8 diketahui bahwa perlakuan penambahan konsentrasi terbaik yang mendekati nilai pembanding komersial adalah konsentrasi $\mathrm{CaCO}_{3} 5 \%$, yang dapat dideskripsikan memiliki nilai rata-rata uji rangking ke-2 (sangat suka), uji sensori kenampakan 3,0 (netral), aroma 4,3 (suka), rasa 3,3 (netral) dan tekstur 4,0 (suka).
Perbandingan analisis proksimat hasil penelitian dengan produk komersial dapat dilihat pada Tabel 4 . Kadar air sangat mempengaruhi mutu tepung puding instan. Nilai kadar air pada tepung puding instan alginat terpilih $\left(\mathrm{CaCO}_{3} 5 \%\right)$ merupakan nilai kadar air yang rendah, hal ini dikarenakan oleh sifat dari $\mathrm{CaCO}_{3}$ yang dapat menangkap air sehingga dapat menurunkan kadar air. Lesmana et al. (2008) menyatakan bahwa semakin meningkat $\mathrm{CaCO}_{3}$ yang ditambahkan maka dapat menurunkan kadar air yang disebabkan oleh kemampuan dalam memerangkap air. Nilai kadar air yang rendah pada tepung puding instan alginat diharapkan dapat memperpanjang umur simpan dari tepung puding instan alginat. Produk yang mempunyai kadar air rendah biasanya mempunyai masa simpan yang lebih lama dibandingkan dengan produk yang mempunyai kadar air tinggi (Siswati, 2002).

Nilai kadar abu pada tepung puding instan terpilih merupakan nilai kadar abu yang tinggi, diduga karena adanya penggunaan $\mathrm{CaCO}_{3}$ pada tepung puding instan terpilih. Winarno (1996) menyatakan bahwa komponen yang mempengaruhi kadar abu terdiri dari kalsium, kalium, natrium, besi, mangan, magnesium dan iodium.

Hasil analisis kandungan lemak puding instan alginat terpilih lebih rendah $(0,41 \%)$ dari tepung puding instan produk komersial sebesar $5 \%$. Rendahnya nilai kadar lemak pada tepung puding instan terpilih diduga karena beberapa bahan yang digunakan sebagai penyusun tepung puding alginat terdiri dari gula, aginat dan susu skim dan diketahui bahwa susu skim memiliki kadar lemak yang rendah namun kadar proteinnya tinggi.

Hasil analisis kandungan protein tepung puding instan terpilih $(3,67 \%)$ lebih tinggi dibandingkan tepung puding instan produk komersial yang memiliki nilai kadar protein sebesar $3 \%$. Tingginya kadar protein

Tabel 4. Karakteristik mutu kimia dan fisik tepung puding instan

Table 4. Physicochemical characteristics of instant pudding powder

\begin{tabular}{lcc}
\hline \multicolumn{1}{c}{ Parameter/Parameters } & $\begin{array}{c}\text { Tepung Puding instan } \\
\text { Terpilih/Instant Pudding } \\
\text { Powder Selected }\end{array}$ & $\begin{array}{c}\text { Puding Instan Komersial (tertera } \\
\text { dalam kemasan)/Commercial Instant } \\
\text { Pudding (showed in the packaging) }\end{array}$ \\
\hline Kadar air/Moisture content (\%) & $2.70 \pm 0.13$ & - \\
Kadar abu/Ash content (\%) & $14.96 \pm 3.57$ & - \\
Kadar lemak/Fat content (\%) & $0.41 \pm 0.08$ & 5 \\
Kadar Protein/Protein content (\%) & 3.67 & 3 \\
Karbohidrat by difference (\%) & 78.26 & 11 \\
$a_{w}$ & $0.23 \pm 0.01$ & - \\
\hline
\end{tabular}


tepung puding instan terpilih diduga berasal dari susu skim yang digunakan pada bahan formulasi sebagai bahan penyumbang protein tertinggi pada tepung puding instan alginat.

Karbohidrat memiliki peranan penting dalam menentukan karakteristik bahan makanan misalnya rasa, warna, tekstur dan lain-lain (Winamo, 2008). Berdasarkan Tabel 4 dapat dilihat bahwa kadar kabohidrat tepung puding instan terpilih lebih tinggi dibandingkan nilai tepung puding instan komersial. Kadar karbohidrat pada tepung instan terpilih lebih tinggi, karena adanya kandungan susu skim dan gula jagung sehingga kandungan karbohidrat lebih tinggi. Kadar karbohidrat yang tinggi pada puding instan alginat dapat dimanfaatkan sebagai sumber karbohidrat konsumen.

Berdasarkan hasil analisis $a_{w}$ diketahui bahwa nilai $a_{w}(0,23)$ pada tepung puding instan terpilih termasuk rendah, sehingga diharapkan tepung puding instan alginat tahan terhadap serangan mikroba. Menurut Winarno (2008), $a_{w}$ adalah jumlah air bebas yang dapat digunakan oleh mikroorganisme untuk pertumbuhannya. Berbagai mikroorganisme mempunyai $a_{w}$ minimum agar dapat tumbuh.

\section{Karakteristik Mikrobiologi}

Kerusakan pada bahan pangan disebabkan oleh beberapa faktor, antara lain pertumbuhan serta aktivitas mikroba dan aktivitas enzim-enzim di dalam bahan pangan. Salah satu cara mencegah pertumbuhan mikroba adalah dengan mengganggu lingkungan hidupnya. Lingkungan hidup mikroba dapat diganggu dengan cara mengubah suhu, kadar air, $a_{w}, p H$, kadar oksigen, komposisi substrat serta penggunaan bahan pengawet antimikroba (Effendi, 2009).

Nilai ALT tepung puding instan terpilih yaitu $<25 \mathrm{x}$ $10^{2} \mathrm{cfu} / \mathrm{g}$, sedangkan nilai ALT pada puding instan komersil yaitu $8,7 \times 10^{3} \mathrm{cfu} / \mathrm{g}$. Rendahnya nilai ALT diduga karena produk tepung puding instan memiliki $a_{w}$ rendah yaitu 0,23 sehingga memungkinkan bakteri sulit tumbuh dan berkembang di dalamnya. Penyebab lainnya diduga karena pada proses pembuatan tepung puding instan dilakukan dengan memperhatikan sanitasi yang baik serta waktu pengujian produk yang dilakukan tidak lama setelah proses pembuatan tepung puding instan sehingga meminimalisasi kemungkinan kontaminasi dari lingkungan terhadap produk. Bakteri umumnya tumbuh dan berkembang biak dengan baik dalam media dengan $a_{w}$ tinggi $(0,75-$ 1,00) (Buckle et al., 1987).

\section{KESIMPULAN}

Formula produk tepung puding instan terbaik pada penelitian ini adalah pudding instan dengan penambahan konsentrasi $\mathrm{CaCO}_{3} 5 \%$ yang memiliki nilai kekuatan gel sebesar $168,84 \mathrm{~g} / \mathrm{cm}^{2}$, nilai elastisitas sebesar $43,09 \mathrm{~mm}$ dan nilai sineresis sebesar 3,38\%. Pada hasil uji organoleptik, tepung puding instan terpilih mendapatkan nilai rata-rata uji rangking 45 (sangat suka), uji sensori kenampakan 3,0 (netral), aroma 4,3 (suka), rasa 3,3 (netral) dan tekstur 4,0 (suka).

Berdasarkan analisis mutu tepung puding instan terbaik memiliki nilai kadar air sebesar 2,70 $0,13 \%$, nilai kadar abu sebesar $14,96 \pm 3,57 \%$, nilai kadar lemak sebesar $0,41 \pm 0,08 \%$, nilai kadar protein sebesar $3,67 \%$, nilai kadar karbohidrat by difference sebesar $78,26 \%$ dan $a_{w}$ sebesar $0,23 \pm 0,01$. Sedangkan pada analisis mikrobiologi tepung puding instan terbaik memiliki nilai rata-rata angka lempeng total $(A L T)$ yaitu $<25 \times 10^{2} \mathrm{koloni} / \mathrm{g}$.

\section{DAFTAR PUSTAKA}

Anggadiredja, J.T., Zatnika, A., Purwoto, H., \& Istini, S. (2010). Rumput Laut. Cetakan Kelima. Penebar Swadaya, Depok. p.134 .

[AOAC] Association of Official Analytical Chemyst.(1994). Official Methods of Analysis. Arlington, Virginia, USA: Published by The Association of Official Analytical Chemist, Inc.

[BSN] Badan Standarisasi Nasional. (2006a). Analisa Kimia Pada Produk Perikanan. SNI 01-2354-2006. Kementrian Kelautan dan Perikanan, Jakarta. 32 p.

[BSN] Badan Standarisasi Nasional. (2006b). Standar Penentuan Angka Lempeng Total (ALT). SNI 012332.3-2006. Kementrian Kelautan dan Perikanan, Jakarta. $11 \mathrm{p}$.

[BSN] Badan Standarisasi Nasional. 2009. Standar Nasional Indonesia Rumput Laut Kering. SNI 2690.1:2009. Kementrian Kelautan dan Perikanan, Jakarta. 8 p.

[BSN] Badan Standarisasi Nasional. 2011. Petunjuk Pengujian Organoleptik Atau Sensori Pada Produk Perikanan. SNI 2346-2006. Kementrian Kelautan dan Perikanan, Jakarta. 136 pp.

Buckle, K.A., Edwards, R,A., Fleet, G,H., \& Wooton, M. (1987). Dalam Purnomo, H. dan Adiono (penerjemah). IImu Pangan. UI Press, Jakarta. 365 p.

Darmawan, M., Utomo, B.S.B., \& Mulia, R.A.Y. (2013). Kualiatas alkali treated cottonii (ATC) yang dibuat dari rumput laut Eucheuma cottonii yang berasal dari beberapa daerah di Indonesia. Squallen Bulletin of Marine and Fisheries Postharvest and Biotechnology. (8): 117-127.

Draget, K.I. (2000). Alginates. In Philips, G.O. and Williams, P.A. (eds.). Handbook of Hydrocolloids. CRC Press. p. 379-395.

Draget, K.I, Gåserød, O., Aune, I., Anderse, P.O., Storbakken, B, Stoke, B.T., \& Smidsrød, O. (2001). 
Effects Of Molecular Weight and Elastic Segment Flexibility On Syneresis In Ca-Alginate Gels. Food Hydrocolloids. (15): 485-490

Effendi, H.M.S. (2009). Teknologi Pengolahan dan Pengawetan Pangan. Alfabeta, Bandung. 202 pp.

[FCC] Food Chemical Codex. (1981). Food Chemical Codex. $3^{\text {rd }}$ ed. Volume III. National Academic of Science. Washington D.C. p. 155-195.

Hak, N. \& Tazwir. (2004). Pengaruh umur panen rumput laut coklat (Sargassum filipendula) terhadap mutu fisiko-kima natrium alginat yang dihasilkannya. Buletin Teknologi Hasil Perikanan (7): 80-91.

Indriani, H. \& Suminarsih, E. (1999). Budidaya, Pengolahan dan Pemasaran Rumput Laut. Penebar Swadaya, Jakarta. 99 pp.

JECFA (2007). FAO JECFA Monographs 4. published in the Combined Compendium of Food Additive Specifications.

Jothisaraswathi, S., Babu, B. \& Rengasamy, R. (2006). Seasonal studies on alginate and its composition II: Turbinaria conoides (J. Ag.) Kutz. (Fucales, Phaeophyceae) J. Appl Phycol. 18: 161-166.

Lesmana, S.N., Putut, T.I.S., \& Kusumawati, N. (2008). Pengaruh penambahan kalsium karbonat sebagai fortifikan kalsium terhadap sifat fisikokimia dan organoleptik permen jeli susu. Jurnal Teknologi Pangan dan Gizi. (7): 28-39.

Marine Colloids FMC Corp. (1977). Carrageenan. Marine Colloids Monograph One. New Jersey: Marine Colloid Division FMC Coorporation. Springfield. USA.

Marrs, W.M. \& Titoria, P. (2004). Third Generation Gels. In Williams, P.A. and Philips, G.O. (eds.). Gums and Stabilisers for The Food Industry 12. Edited by UK: The Royal Society of Chemistry. pp. 189-200.

Murdinah, Subaryono, Fransiska, D., Sinurat, E., Amini, S., Irianto, H.E., Darmawan, M., \& Peranginangin, R. (2005). Laporan Teknis Pemanfaatan Mikro dan Makro alga. Pusat Riset Pengolahan Produk dan Sosial Ekonomi Kelautan dan Perikanan, Jakarta.

Peranginangin, R., Murdinah, Fransiska, D., Sinurat, E., \& Apriyani, S.N.K. (2010). Laporan Teknis. Penelitian Pengembangan Produk Baru dari Rumput Laut dalam rangka Meningkatkan Nilai Tambah dan
Daya Saing. Balai Besar Litbang Pengolahan Produk dan Sosial Ekonomi Kelautan dan Perikanan, Jakarta.

Ramsden, I. (2004). Plant and algal gums and mucilages. In Chemical and Functional Properties of Food Sachharides. CRC Press LLC. 247-248 p.

Renn, D.W. (1986). Uses of Marine Algae Biotechnology and Industry dalam Summ. Rep. Workshop on Marine Algae Biotechnology. National Academic Press, Washington DC. pp. 42-50.

Siswati, J. (2002). Kajian Ekstraksi Alginat dari Rumput Laut Sargassum sp. serta Aplikasinya sebagai Penstabil Es Krim. Tesis. Program Pascasarjana Institut Pertanian Bogor, Bogor. 70 pp.

Soegiarto, A., Atmadja, W.S., Sulistijo, \& Mubarak, H. (1978). Rumput Laut (Algae): Manfaat, Potensi, dan Usaha Budidaya. LON-LIPI, Jakarta. p. 5-15.

Subaryono. (2009). Karakterisasi Pembentukan Gel Alginat dari Rumput Laut Sargassum sp. dan Turbinaria sp. Tesis. Program Pasca Sarjana, Institut Pertanian Bogor, Bogor. $81 \mathrm{p}$.

Subaryono, Peranginangin, R., Fardiaz, D., \& Kusnandar, F. (2010). Pembentukan Gel Alginat yang Diekstrak dari Sargassum filipendula dan Turbinaria decurrens Menggunakan $\mathrm{CaCO}_{3}$ dan Glucono- $\delta$-lactone (GDL). Jurnal Pascapanen dan Bioteknologi Kelautan dan Perikanan. (5): 43-54.

Subaryono \& Peranginangin, R. (2010). Perbaikan Viskositas dari Sargassum filipendula dan Turbinaria deccurens Menggunakan $\mathrm{CaCO}_{3}$ dan Locust Bean Gum (LBG). Jurnal Pascapanen dan Bioteknologi Kelautan dan Perikanan. (4): 131-139.

Subaryono \& Murdinah. (2011). Kualitas agar-agar dari rumput laut Gracilaria chilensis yang dibudidayakan di Lampung. Prosiding Forum Inovasi Teknologi Akuakultur. p. 1153-1158.

Winarno, F.G. (1996). Teknologi Pengolahan Rumput Laut. Pustaka Sinar Harapan, Jakarta. 103 p.

Winarno, F.G. (2008). Kimia Pangan dan Gizi. M-Brio Press, Bogor. $289 \mathrm{p}$.

Yunizal. (2004). Teknologi Pengolahan Alginat. Pusat Riset Pengolahan Produk dan Sosial Ekonomi Kelautan dan Perikanan, Jakarta. 66 p. 